\title{
Home based education programme for Orang Asli children: an analysis of their educational needs
}

Introduction. In realizing the vision "education for all", the educational development of the Orang Asli children remains a great challenge. Although various initiatives have been implemented by the government of Malaysia, there are still high attrition rates among Orang Asli children in school. Instructional programmes and educational initiatives in schools have been designed for mainstream education and tend to disregard the traditional assimilation of the Orang Asli culture. This may be the reason for the rejection of the mainstream school system among the Orang Asli communities. This study purpose is to determine future allocation of resources compare with presently available to develop home based education program as an alternative education system for Orang Asli to meet their basic needs.

Methodology. A survey study has conducted among the Orang Asli community named Semai settled in Cameron highland, Pahang state of Peninsular of Malaysia. The questionnaire was distributed among 30 participants who are the parents and teachers from the Orang Asli community as well as teachers of the Orang Asli children from a district in Cameron Highlands; Pahang. Likert scale 5 has adopted to determine suitability of mainstream schooling; Forms of Alternative Education and Readiness of Orang Asli children comparing presently available resource with future needs to design the home based education program according to their needs.

Results and Findings. Respondents comprised of Orang Asli parents (50\%) and teachers (50\%) of Orang Asli children, majority respondents are the Orang Asli (56.7\%) followed by Malay (33.3\%). Suitability of mainstream schooling in the presently available resource shows (Mean $=2.51, S D=0.70$ ) shows not up to the standard or do not meet with the Orang Asli children schooling needs however, respondents has shown keen interest to improve for the future development where (Mean $=4.27, S D=0.57)$. Alternative education in the present context showing (Mean $=2.26, S D=0.74)$ where proposed for future showing (Mean $=4.72, S D=0.92$ ). Lastly, readiness of Orang Asli children in presently education shows (Mean $=1.37$, $S D=0.83)$ while in the future propose model and readiness showing strongly agree (Mean $=4.40, S D=0.68)$.

Conclusion. The findings indicate that there is a need for an alternative model of education. A homebased educational programme model is seen as a means to fulfil parents' aspirations and ensure that the values, traditions, beliefs and cultural practices continue to be upheld and are eroded by mainstream education system.

Keywords: alternative education, home-based education programme, homeschooling, Orang Asli children's education, needs analysis

\section{For Reference:}

Abdul Rahman, M. N., Alias, N., DeWitt, D., \& Idris, M. R. (2021). Home based education programme for Orang Asli children: an analysis of their educational needs. Perspektivy nauki $i$ obrazovania - Perspectives of Science and Education, 49 (1), 329-337. doi: 10.32744/pse.2021.1.23 


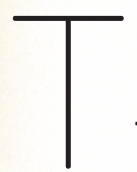

he indigenous people of Malaysia are known as the Orang Asali are indigenous to Peninsular Malaysia. There are 18 ethnic groups of Orang Asli officially recorded: Temiar, Semai, Lanoh, Semnan, Sabum, Kensiu, Batek, Kentaq Bong, Jehai, Medrique, Tonga, Temuan, Jakun, Orang Kanaq, and Orang Selitar, and many smaller groups [1]. The Orang Asli remains a minority group in Malaysia comprising only $0.5 \%$ of the total population in Malaysia which is estimated at 141,230 during the 2004 population survey of the department of Orang Asli Affairs [2;3]. Despite the small numbers of Orang Asli in Malaysia, the community has many unresolved issues among education is the core issue. The poor academic achievements and mastery of language, low economic development and psychosocial are the common issues among the Orang Asli. One of the psychosocial issues is the low participation of Orang Asli students in the mainstream education system. This issue continues to be a major problem even after nearly three decades of research and implementation of a range of government policies. According to statistics from the [4] the Orang Asli student dropout rates from secondary schools is relatively high especially during the transition from primary school to secondary school. Study of [5] reported that about $62 \%$ of Indigenous student drop out from school every year and about $94 \%$ not completed their secondary school, dropouts statistics reported [6] among the Orang Asli is recorded as followed 2006: 34.50\%; 2007: 36.10\%; 2008: 31.77\%; and 2009: $29.02 \%$. Problems related to the attrition from school among Orang Asli and low rates of literacy [7] and numeracy continue to plague among the indigenous communities [8]. Study of [9-10] stated that previously implemented policy was dismal failed due to lack of coordination among the community people in the result huge student dropout. The author has link failure reason with socioeconomic poor lifestyle of the Orang Asli, lack of educational awareness. Parental involvement may significantly impact and reduce dropout of the student from the educational sectors [11]. Doctorate study [12] has conducted on the educational dropout and negligence of Orang Asli concluded the reason of educational reform policies failure and Orang Asli lack of interested and dropout from the mainstream schooling. Homeschooling is informal, unstructured education which is completely coordinated and supervised by parents during the mainstream school schedules [13-15]. This form of education is temporary or an alternative to the formal education provided by the government or even private educational institutions. In some countries, home-schooling is a legal acceptable alternative to the mainstream education system and may not require trained teachers [16].

Globalization and the advancement in technologies made possible where anyone can access to the information and knowledge with open education systems and online learning. Hence, home-schooling can be optimised to ensure equity in education among the Orang Asli community. In addition, home-schooling can be used to ensure family ties, traditions and cultures be propagated among the young. This could ensure that the values and traditions of the Orang Asli community could be preserved. Having an education system specific to the needs of the community could address the issue of the high attrition rates among Orang Asli children especially if it catered to the needs of the Orang Asli children themselves. This research focus on the educational needs of the Orang Asli children will be analysed to identify issues which needs to be addressed in mainstream schooling and to determine the possibility of implementing a home-based or home-schooling educational 
programme model. In the past, home based education program organised by Australian parents discussed [17]. Home based education program in Malaysia is widely discussed in the studies conducted by [18; 19]. Study discussed school refusal of negative children or indigenous children were thought home based education [20]. Early studies conducted in Malaysia was also recommended home based education program for orange [21] in contrast studies $[22 ; 23]$ have suggested home-based education programme to provide an alternative education in rural areas. Studies of [24-26] discussed the resources in a learning community for home-based education programme. The Orang Asli children require an educational program as they are in the rural interiors and hinterlands, and may require different needs and resources in their community to live in the jungles of the interiors from other Malaysian communities. In addition, the parents and members of the community as stakeholders should be accountable in transmitting the indigenous knowledge of their community in order to preserve it for posterity. Hence, a model of home-based education and home-schooling specific to the Orang Asli community is required. Home based education programme model development for Orang Asli children may need to be different from the concept of home based education programme practiced by the majority of parents in the world. Therefore, a needs analysis to determine the suitability and requirements in the context of home based education programme model of education of Orang Asli children in the future is focused part of this study. The second part comprised of three domains: Suitability of Mainstream Schooling; Forms of Alternative Education and Readiness of Orang Asli children. The objectives of the study is set to understand the issues of mainstream schooling and home based education programme model development needs in the future for Orang Asli children. Hence the following research questions are addressed: What are the views of teachers and parents on issues of current Orang Asli mainstream schooling in the context of the study of Orang Asli children? What is the difference between the views of teachers and parents for home based education programme model development needs in the future in the context of the study of Orang Asli children?

\section{Methodology}

Questionnaire survey study was conducted among the largest ethnic group of Orang Asli named Semai settled in Cameron highland, Pahang state of Peninsular of Malaysia. The questionnaire was distributed among 30 participants who are the parents and teachers from the Orang Asli community as well as teachers of the Orang Asli children from a district in Cameron Highlands, Pahang.

Demographic followed by the second part comprised on Suitability of Mainstream Schooling; Forms of Alternative Education and Readiness of Orang Asli children. Likert scale 5-point was used in this study where 1-strongly disagree and 5 strongly agree.

Results

The participants involved two main groups of parents who are Orang Asli and teachers of Orang Asli children. The respondents were of two categories: teachers of Orang Asli children and teachers in primary schools with Orang Asli children. Table 1 shows the demographics of the respondents. 
Table 1

Demographics of Respondents

\begin{tabular}{|l|c|c|}
\hline \multicolumn{1}{|c|}{ Status } & Frequency & Percentage (\%) \\
\hline Parent & 15 & 50 \\
\hline Teacher Ethnicity & 15 & 50 \\
\hline & Frequency & Percentage (\%) \\
\hline Malay & 10 & 33.3 \\
\hline Chinese & 1 & 3.3 \\
\hline India & 2 & 6.7 \\
\hline Orang Asli & 17 & 56.7 \\
\hline $\mathrm{N}=30$ & & \\
\hline
\end{tabular}

Table 1 show respondents comprised of Orang Asli parents (50\%) and teachers (50\%) of Orang Asli children (including Orang Asli teachers). The majority of respondents in this study were represented by Orang Asli (56.7\%) comprising of 15 Orang Asli parents and 2 teachers. The rest were experienced teachers teaching Orang Asli children with more than 5 years of teaching experience in primary schools.

\section{Challenges faced by Orang Asli}

This study focused on the perceptions of teachers and parents present issues of Orang Asli children in mainstream schooling and home based education programme in order to determine the future needs of the Orang Asli children. The perceptions of teachers and parents of Orang Asli were analysed in three domains: Suitability of Mainstream Schooling; Forms of Alternative Education and Readiness of Orang Asli children.

\section{Suitability of the Mainstream Schooling for Orang Asli children}

The perception regarding mainstream schooling were analysed in the present and future context by keeping their main needs accordingly. Table 2 shows the present and future sustainability of mainstream schooling for Orang Asli children in the present and the anticipated needs for the development of a home based education programme model in the future is analysed.

Table 2

Present and Future Suitability of Mainstream Schooling for Orang Asli children

\begin{tabular}{|l|c|c|c|c|c|}
\hline \multirow{2}{*}{ Suitability of Mainstream School System } & \multirow{2}{*}{ N } & \multicolumn{3}{c|}{ Present } & \multicolumn{2}{c|}{ Future } \\
\cline { 3 - 6 } & & Mean & SD & Mean & SD \\
\hline School Time & 30 & 2.57 & 0.82 & 4.27 & 1.08 \\
\hline Curriculum & 30 & 2.53 & 0.77 & 4.30 & 1.02 \\
\hline The distance between the place of residence to the school & 30 & 2.43 & 0.77 & 4.50 & 0.94 \\
\hline Values of the community & 30 & 2.37 & 0.67 & 4.77 & 0.57 \\
\hline Suitability of Socio-cultural Community & 30 & 2.67 & 0.74 & 4.73 & 0.52 \\
\hline
\end{tabular}

The results of the study showed that the respondents disagreed on the present situation of the mainstream school for Orang Asli children as it did not seem in accordance with the socio-cultural aspect of Orang Asli community (Mean $=2.67, \mathrm{SD}=0.74$ ), the suitability of 
the distance between the place of residence of Orang Asli community with the mainstream schools (Mean $=2: 43, S D=0.77$ ), the suitability of the curriculum (Mean $=2: 53, \mathrm{SD}=$ 0.77 ), the appropriateness of mainstream school hours (Mean $=2: 57, S D=0.82$ ) and the appropriateness of the values of the community (Mean $=2: 37, S D=0.67$ ).

The results of the study showed that the respondents' expectations of the development of a home-schooling model should take into account the needs for the future as the respondents strongly agreed that an appropriate Orang Asli home-schooling model would take into account the appropriateness of the schooling hours (Mean $=4: 27, S D=1: 08$ ), the suitability of the curriculum (Mean $=4: 30, S D=1: 02$ ), the suitability of the distance between the place of residence to the school (Mean $=4: 50, S D=0.94$ ), the appropriateness of the values of the community (Mean $=4.77, S D=0.57$ ) and the suitability of the socio-cultural aspect of Orang Asli communities (Mean $=4.73, \mathrm{SD}=0.53$ ). In summary, the respondents in the context of this research perceived that the current situation in mainstream schooling was not suitable for the education of Orang Asli children with respect to the curriculum, the distance between the place of residence to the school, values of the community and suitability of the socio-cultural aspect of the community in the current school environment. Respondents perceived that the expectations for the future development of a home based education programme model should be based on their needs as table 2 findings indicated would meet the educational needs of the Orang Asli children.

\section{Alternative forms of education for Orang Asli children}

The perception regarding the provision of alternative education for Orang Asli children in the present and the anticipated needs for the development of a home based education programme model in the future is reviewed and analysed as findings shown in Table 3.

Table 3

Present and Future Alternative Education forms for Orang Asli children

\begin{tabular}{|l|c|c|c|c|c|}
\hline \multirow{2}{*}{\multicolumn{1}{|c|}{ Alternative forms of education }} & \multirow{2}{*}{$\mathrm{N}$} & \multicolumn{2}{c|}{ Present } & \multicolumn{3}{c|}{ Future } \\
\cline { 3 - 7 } & & Mean & SD & Mean & SD \\
\hline Vocational Education & 30 & 2.37 & 0.96 & 4.80 & 0.61 \\
\hline Home based education programme & 30 & 2.67 & 0.74 & 4.43 & 0.68 \\
\hline Special School & 30 & 2.40 & 0.81 & 4.37 & 0.76 \\
\hline Distance Education & 30 & 2.17 & 0.80 & 3.97 & 1.30 \\
\hline
\end{tabular}

The findings in Table 3 indicated that respondents disagreed with the presently available alternative sources or form of education which was considered suitable for Orang Asli children. The respondents disagreed on distance education (Mean $=2: 17, \mathrm{SD}=0.80$ ), special schools (Mean $=2: 40, \mathrm{SD}=0.81$ ); home based education programme education (Mean $=2.67, \mathrm{SD}=0.74$ ) and vocational skills-based education (Mean $=2: 37, \mathrm{SD}=0.96$ ) as an alternative to the mainstream school system for Orang Asli children.

However, the respondents' expectations of the development of a home-schooling model should take into account the needs for the future as the respondents strongly agreed that an appropriate Orang Asli homeschooling model would take into account the alternative forms of education such as vocational education (Mean $=4.80, S D=0.61$ ), home based education programme (Mean $=4: 43, S D=0.68$ ), special schools (Mean $=4.97$, SD 1.30) and distance education programmes (Mean $=3.97, \mathrm{SD}=1.30$ ). In summary, with the presently 
available alternative sources of education is not sufficient to meet the educational needs of the Orang Asli children. Where respondents perceived that the expectations for the development of a home based education programme model in the future would consider the educational needs of the Orang Asli children and to apply the values and practices of indigenous traditions.

\section{Readiness to learn among Orang Asli children}

The readiness to learn for Orang Asli children in the mainstream school system in the present and the anticipated needs for the development of a home based education programme model in the future is analysed and findings shown in Table 4.

Table 4

The readiness to learn among Orang Asli children

\begin{tabular}{|l|c|c|c|c|c|}
\hline \multirow{2}{*}{ Learning readiness } & \multirow{2}{*}{$\mathrm{N}$} & \multicolumn{2}{c|}{ Present } & \multicolumn{2}{c|}{ Future } \\
\cline { 3 - 7 } & & Mean & SD & Mean & SD \\
\hline Emotional Intelligence & 30 & 1.70 & 0.84 & 3.40 & 1.25 \\
\hline Efficiency of Social interaction & 30 & 1.37 & 0.56 & 4.50 & 0.68 \\
\hline Intellectual Ability & 30 & 1.70 & 0.75 & 4.40 & 0.62 \\
\hline Maturity & 30 & 1.47 & 0.63 & 4.10 & 1.09 \\
\hline
\end{tabular}

The findings indicated that the respondents strongly disagreed on the present situation of learning readiness among the Orang Asli children in the mainstream school system. Currently in mainstream schools, there is not enough attention paid to the efficiency of social interaction (Mean $=1: 37, S D=0.56$ ) among Orang Asli children. In addition, respondents also strongly disagreed that the mainstream school system currently considered the readiness of the children to learn by taking into account the maturity of the Orang Asli children (Mean $1: 47, S D=0.63$ ), their emotional intelligence (Mean $=1.70, S D=0.84$ ) and intellectual ability (Mean $=1.70, S D=0.75)$. The results of the study showed that the respondents' expectations of the development of a home-schooling model should take into account the needs for the future as the respondents strongly agreed that an appropriate Orang Asli homeschooling model would take into account the efficiency of social interaction (Mean = $4: 50, S D=0.68)$, intellectual ability (Mean $=4: 40, S D=0.62$ ) and personal maturity among the Orang Asli children (Mean $=4: 10, S D=1: 09$ ). Respondents were not so sure on their willingness to learn aspects of emotional intelligence among Orang Asli children (Mean = 3.40 and $S D=1.25$ ). In summary, findings show that presently the readiness in mainstream schooling was not suitable for the education of Orang Asli children. Respondents perceived that the expectations for the development of a home based education programme model in the future would meet the educational needs of the Orang Asli children.

\section{Discussion and implication of study}

This study was conducted to identify the needs to design an appropriate a model home based education program for Orang Asli children. The needs analysis was conducted to identify the current challenges and issues of Orang Asli children's education in mainstream schooling. The problem of education for children of indigenous peoples such as they dropout of school was discussed in the studies such as [5] discussed Orang Asli dropout from 
the school in Melaka state of Malaysia refer to [7] highlighted problems among Orang Asli education dropout. Among the Orang Asli school dropout largely discussed [9; 11] as the core issue in the implemention of education polices. Study [27-29] postulated the prevention of dropout children from the school especially among Orang Asli community in Malaysia and the identity issue among Orang Asli children [16]. The findings of the needs analysis indicated that mainstream school system as being practiced currently is not in keeping with the aspirations and desires of the education of Orang Asli community. The mainstream curriculum being used is not concerned with the traditions and practices of the Orang Asli community. Moreover, mainstream schools were too far away from Orang Asli settlements and it is too difficult for parents to send their children to school. Additionally, what was more worrying for parent's moral values and the practice of teaching in mainstream schooling failed to inculcate good moral values among Orang Asli children. Values taught in mainstream schools did not emphasize on social-cultural values and traditions of the Orang Asli community. Mainstream school environment also did not developed according to the socio-cultural norms of the Orang Asli community. Therefore, there is a need to develop a model of homeschooling for the Orang Asli children's education based in the future education needs for the indigenous peoples. Most of the respondents strongly agreed that alternative home based education programmes are needed to meet the educational needs of the Orang Asli children in the future, especially in developing values and practices as well as socio-cultural traditions of indigenous peoples in every Orang Asli child. The findings of the analysis of the readiness to learn about Orang Asli children, particularly emotional intelligence, and efficiency of social interaction, intellectual ability and maturity of the Orang Asli child in the mainstream school system did not meet the educational needs of Orang Asli children. Learning and teaching Orang Asli children in mainstream schools conducted in accordance with the level of children's readiness generally, in mainstream schooling. Thus, the development of home-based education model programme for Orang Asli children in the future are expected to keep the level of learning readiness Orang Asli children

\section{Conclusion and suggestion}

Based on the survey study findings conclusions can be made regarding the need for the development of home based education model program for Orang Asli children in Malaysia. In addressing the issue of Orang Asli child's education, adaptation alternative home based education program a recommendation of education based option education to Orang Asli children should consider by all stake holders. Orang Asli parents should be given the choice and opportunity to determine the best form of education for their children. There is a need to develop model home based education program for Orang Asli children to enable parents to design their own curriculum and tradition of the desired value in the identity formation of her children $[3 ; 16]$ made similar conclusion in their study. It concluded that the learning process takes place, namely trans-generational experiences, absorption and partnership from generation to generation [30]. The needs for the development of home-based education model program for children learning with concept Orang Asli communities that Orang Asli students who undergo home based education programmed allowed to participate in extracurricular activities, undergoing experimental science laboratories and specific guidance on literacy and numeracy in public schools at the appropriate time period. Cooperation between the school and the Orang Asli community, the education of Orang Asli children 
can expose new dimension leading to fewer dropouts in the Orang Asli communities. Home based education designed based on their needs and requirements will certainly give more confidence to the parents to send their children to school because of the skills, traditions and way of life that would be passed on to the children met in the home based education model. Concerns about the impact of parental socialization and assimilation that erode the culture, traditions and ethnic Orang Asli holdings through school institutions will reduced. In conclusion, efforts to integrate Orang Asli students in mainstream schools do not be one of the ways in which the integration of different cultures recognized, otherwise it becomes a program in which students assimilate Orang Asli people will be absorbed into the dominant society also concluded by [31]. This phenomenon is a major issue in the education of their Orang Asli children today where parents continue to marginalize public school on grounds of viability. Thus, through the development of education on home based education program model for Orang Asli children, can develop the personality of children with the inherited tradition of ethnic culture without sacrificing academic education.

\section{Acknowledgements}

Funding of this research work is generously supported by the Fundamental Research Grant Scheme (FRGS), FP026-2017A dan Impact Oriented Interdisciplinary Research Grant - IIRG010C-19SAH

\section{REFERENCES}

1. Endicott, K. (Ed.). (2015). Malaysia's original people: Past, present and future of the Orang Asli. NUS Press.

2. Masron, T., Masami, F., \& Ismail, N. (2013). Orang Asli in Peninsular Malaysia: population, spatial distribution and socio-economic condition. J Ritsumeikan Soc Sci Humanit, 6, 75-115.

3. Abdullah, M. N. L. Y., \& Primus, D. (2020). The impact of institutional support and student engagement on educational outcomes of Orang Asli students at public universities. Asia Pacific Journal of Education, 1-16.

4. Jabatan Kemajuan Orang Asli. (2014). Retrieved: https://www.jakoa.gov.my/.

5. Singar, S. N., \& Zainuddin, A. (2017). Exploring the School Dropout Factors among Indigenous Students in Melaka. Journal of Administrative Science Special Edition: Socio-Economic Issue, 14(3).

6. Kamarulzaman Kamaruddin \& Osman Jusoh. 2008. Educational policy and opportunity of Orang Asli: A study on indigenous people in Malaysia. The Journal of Human Resource and Adult Learning. 4(1):86-97

7. Carey, Iskandar (1976). Orang Asli: The Orang AsliTribes Of Peninsular Malaysia. Oxford University Press.

8. Said, A. M., Alias, N., \& Siraj, S. (2017). Keperluan Model Kurikulum Berasaskan Intelektualisme Perubatan Herba Masa Depan. JuKu: Jurnal Kurikulum \& Pengajaran Asia Pasifik, 3(1), 1-9.

9. Othman, O. (2010). Transformasi Sosial Masyarakat Orang Asli: Satu Kajian Kes di Perkampungan Orang Asli RPS Betau, Kuala Lipis, Pahang (Doctoral dissertation, Jabatan Antropologi dan Sosiologi, Fakulti Sastera dan Sains Sosial, Universiti Malaya).

10. Kamaruddin, K., \& Jusoh, O. (2008). Educational policy and opportunities of Orang Asli: A study on indigenous people in Malaysia. The Journal of Human Resource and Adult Learning, 4(1), 86-97.

11. Juli Edo, (1984). Bentuk Pendidikan Dan Masalah Pencapaian Akademik Orang Asli Masa Kini, Simposium Pembangunan Dan Masa Depan Orang Asli Di Malaysia, 26 Nov 1984, UKM

12. Saedah Siraj \& Vanitha, T., 2010. A Literasi Pedagogy For Orang Asli Students: Bsome Theoretical Consideration. Kertas Kerja Ini Dibentangkan Di Persidangan Inovasi Dalam Penyelidikan Pendidikan. (13 Julai 2010) Universiti Malaya: Kuala Lumpur.

13. Icmi, A. A. N., \& Suryono, Y. (2019). The Role of Homeschooling in the Modern Era. KnE Social Sciences, 511-518.

14. Whitehead, J. W., \& Bird, W. R. (1984). Home education and constitutional liberties: The historical and constitutional arguments in support of home instruction (No. 2). Good News Pub.

15. Isenberg, E. J. (2007). What have we learned about homeschooling? Peabody Journal of Education, 82(2-3), 387409.

16. Alias, N., \& Rahman, M. (2013). A Model of Homeschooling Based on Technology in Malaysia. Malaysian Online Journal of Educational Technology, 1(3), 10-16. 
17. Barratt-Peacock, J. (1997). The why and how of Australian home education (Doctoral dissertation, La Trobe University).

18. EBINEZAR, J. A., \& Rajamony, L. Y. (2008). The Malaysian Experience in Home Schooling (Doctoral dissertation, Doctoral Dissertation, Universiti Putra Kuala Lumpur, Malaysia).

19. Jackson, G. M. (2009). 'More Than One Way to Learn': Home Educated Students' Transitions Between Homeand School (Doctoral dissertation, Monash University).

20. Stroobant, E., \& Jones, A. (2006). School refuser child identities. Discourse: Studies in the cultural politics of education, 27(2), 209-223.

21. Norlidah Alias, Mohd Nazri Abdul Rahman \& Sadah Siraj (2013). Home based education programme: Pembangunan Intelektualisme Orang Asli. Kertas Kerja Ini Dibentangkan Di Persidangan Intelektual Kebangsaan Malaysia 2013. (17-18 April 2013) Universiti Pendidikan Sultan Idris: Tanjung Malim.

22. Kirk, J., \& Winthrop, R. (2006). Home-based schooling: access to quality education for Afghan girls. Journal of Education for International Development, 2(2), 1-9.

23. Kostelecka, Y. (2017). Home education in the post-Communist countries: Case study of the Czech Republic. International Electronic Journal of Elementary Education, 3(1), 29-44.

24. Harding, T. (2006). A study of Victorian home educator-Home school law reforms. In Home Education Symposium and Parliamentary Presentation, Camberwell Civic Centre and Victorian Parliament, Melbourne.

25. Jackson, G. (2007). Home education transitions with formal schooling: Student perspectives. Issues in Educational Research, 17(1), 62-84.

26. Hadderman, M. (2002). Homeschooling. Trends and Issues. Eugene, OR: Educational Management, College Of Education, University Of Oregon. (ERIC Clearsinghouse No. Ed 473001

27. Yanai, S. K. P. (2001). Masalah keciciran pendidikan di kalangan anak-anak Orang Asli (Doctoral dissertation, Jabatan Antropologi dan Sosiologi, Fakulti Sastera dan Sains Sosial, Universiti Malaya, 2000/01.).

28. Santha Kumar Payani Yanai (2001). Masalah Keciciran Pendidikan Dalam Kalangan Anak-Anak Orang Asli, Latihan Ilmiah (Tidak Diterbitkan) Universiti Malaya: Kuala Lumpur

29. Nor, S. M., Roslan, S., Mohamed, A., \& Hassan, K. H. (2011). Dropout prevention initiatives for Malaysian indigenous Orang Asli children. International Journal on School Disaffection, 8(1), 42-56.

30. Battiste, M., Bell, L., \& Findlay, L. M. (2002). Decolonizing education in Canadian universities: An interdisciplinary, international, indigenous research project. Canadian Journal of Native Education, 26(2), 82.

31. Kirkness, V. J., \& Bowman, S. S. (1992). First Nations and schools: Triumphs and struggles. Canadian Education Association.
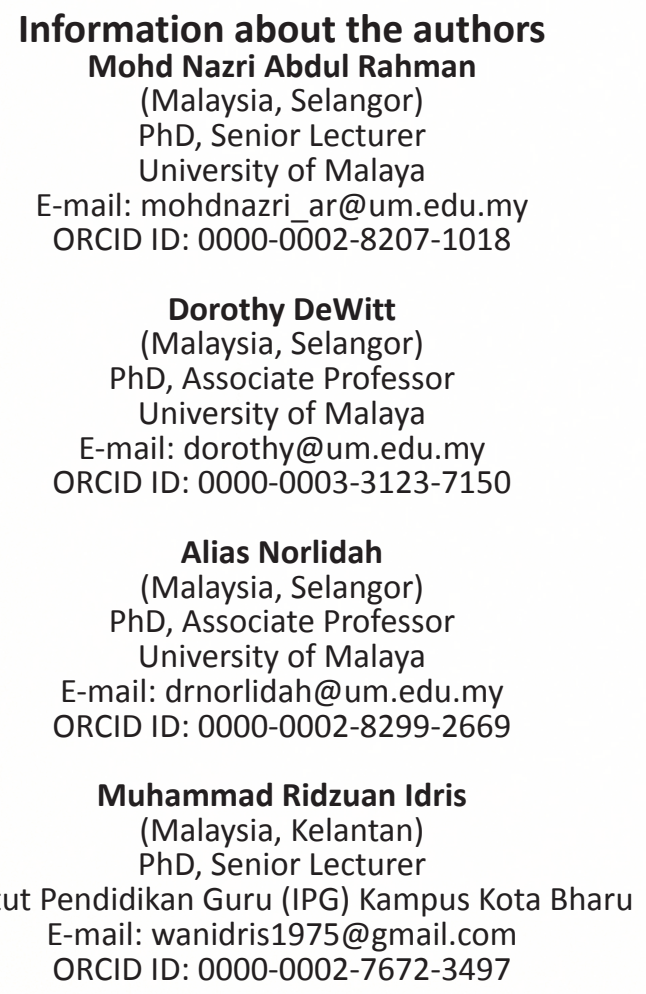